\title{
Upaya Meningkatkan Motivasi Siswa SMA Masuk Program Studi Pendidikan Kimia FKIP UNRAM Melalui Pengenalan Praktikum Kimia Sederhana di SMAN 1 Pringgarata
}

\author{
Eka Junaidi $^{{ }^{*} \text {, Aliefman Hakim }}{ }^{1}$, Saprizal Hadisaputra ${ }^{1}$, Lalu Rudyat Telly Savalas ${ }^{1}$

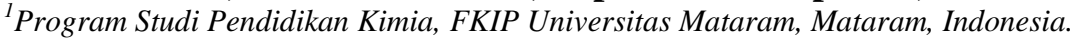

DOI: https://doi.org/10.29303/jpmsi.v2i1.14

Citation: Junaidi, E., Hakim, A., Hadisaputra, S., Savalas, L. R.T. 2020. Upaya Meningkatkan Motivasi Siswa SMA Masuk Program Studi Pendidikan Kimia FKIP UNRAM Melalui Pengenalan Praktikum Kimia Sederhana di SMAN 1 Pringgarata. Jurnal Pengabdian Masyarakat Sains Indonesia (JPMSI). 2(1): 69-72.

\section{Article history}

Received: November $27^{\text {th }} 2019$

Revised: Mei $09^{\text {th }} 2020$

Accepted: Mei $28^{\text {th }} 2020$

*Corresponding Author: Eka Junaidi, FKIP Universitas Mataram, Mataram, Indonesia; Email: xjuned@yahoo.com

\begin{abstract}
Abstrak: Kegiatan pengabdian ini bertujuan untuk Meningkatkan Motivasi Siswa SMA Masuk Program Studi Pendidikan Kimia FKIP Unram melalui pendekatan pengenalan Praktikum Kimia Sederhana. Kegiatan ini dilaksanakan di SMAN 1 Pringgarata. Melalui kegiatan ini diharapkan anggapan siswa pada mata pelajaran kimia yang termasuk pelajaran yang sulit, membosankan, menakutkan dan sebagainya secara perlahan dapat dikurangi dengan demikian motivasi siswa masuk program studi pendidikan kimia FKIP Unram dapat ditingkatkan. Adapun Metode pelaksanaan pengabdian yang lakukan pada pengabdian ini melalui serangkaian kegiatan di SMAN 1 Priggarata, diantaranya :1). Sosialisasi (ceramah dan diskusi) pentingnya Pelaksanaan kegiatan Praktikum, 2). Mendemostrasikan contoh praktikum sederhana menggunakan alat dan bahan praktikum sederhana yang mudah dijumpai di lingkungan sekitar. Kegiatan ini dilaksanakan pada hari Selasa tanggal 29 Oktober 2019, yang diikuti oleh Siswa SMAN 1 Pringgarata Kab. Lombok Tengah yang terdiri atas perwakilan kelas XII IPA 1, Kelas XII IPA 2 dan kelas XII IPA 3 dengan total peserta sebanyak 47 orang (dari 50 siswa yang diundang). Secara keseluruhan kegiatan ini dikatakan berhasil (kehadiran peserta mencapai 94\%). Dalam pelaksanaan kegiatan ini terlihat sikap antusias yang ditunjukkan siswa dalam mengikuti setiap tahapan kegiatan yang dilakukan terutama saat kegiatan tanya jawab interaktif pengenalan alat praktikum sederhana, demonstrasi praktikum sederhana. Dengan demikian harapan dan tujuan dari kegiatan pengabdian di SMAN 1 Pringgarata Kab. Lombok Tengah ini dapat dikatakan tercapai.
\end{abstract}

Kata Kunci : Praktikum Kimia Sederhana, Motivasi, Kemitraan, SMA

\section{Pendahuluan}

Seiring dengan pertumbuhan jumlah Pada jenjang pendidikan tingkat menengah, mata pelajaran kimia hadir sebagai bagian dari Ilmu Pengetahuan Alam, disamping ada pelajaran Biologi dan Fisika. Namun berdasarkan hasil observasi di sekolah saat pembimbingan PPL mahasiswa, bentuk penerimaan siswa pada mata pelajaran kimia relatif kurang dan sering menjadi masalah bagi sebagian siswa. Hal tersebut dapat terlihat dari bagaimana respon siswa saat pembelajaran kimia di sekolah sedang berlangsung.
Setiap kali ditanyakan, bagaimana respon mereka terhadap pelajaran kimia, kebanyakan dari mereka menjawab, pelajaran kimia adalah pelajaran yang sangat sulit, membosankan, menakutkan dan sebagainya. Kami menduga respon mereka seperti itu terhadap pelajaran ini dapat disebabkan oleh beberapa faktor diantaranya materinya yang relatif sulit karena kebanyakan teori yang bersifat abstrak, hitungan-hitungan yang rumit atau metode pembelajaran yang diterapkan guru kurang bervariatif. Kompleksitas masalah tersebut tidak jarang membuat siswa acuh tak acuh terhadap mata 
Junaidi et al, Jurnal Pengabdian Masyarakat Sains Indonesia 2020, 2 (1): 69-72. DOI : https://doi.org/10.29303/ipmsi.v2i1.14

pelajaran kimia. Kunci keberhasilan proses belajar mengajar ilmu kimia di sekolah akan sangat ditentukan oleh kemampuan guru baik dalam pembelajaran di kelas maupun di laboratorium.

Laboratorium kimia mempunyai fungsi yang sangat penting untuk menunjang pencapaian kompetensi standar dan peningkatan kualitas proses belajar mengajar, dan juga untuk meningkatkan minat belajar dan hasil belajar siswa. Salah satu upaya/pendekatan yang dapat dilakukan oleh seorang guru kimia selain menggunakan metode pembelajaran yang tepat juga dapat memadukannya dengan melaksanakan kegiatan praktikum sederhana, dengan menggunakan bahan yang ada di sekitar lingkungan sekolah. Hal ini dimaksudkan supaya kesan abstrak dan rumit serta tidak dapat ditemui dalam kehidupan sehari - hari yang diasumsikan oleh siswa terhadap pelajaran ilmu kimia dapat dihilangkan. Dengan kegiatan praktikum sederhana, pengetahuan teori yang diperoleh siswa dapat diaplikasikan langsung saat kegiatan berlangsung. Sebagai salah satu contoh sederhana adalah pembuatan larutan dengan berbagai konsentrasi hanya bermodalkan labu pengenceran. Contoh lain, Penentuan laju reaksi hanya bermodalkan cangkang telur, gelas beker dan $\mathrm{HCl}$, dan lain-lain sebagainya. Meskipun kegiatan tersebut sangat sederhana namun tetap saja peran serta guru kimia sebagai pembina mata pelajaran kimia sekaligus sebagai pembimbing pelaksanaan praktikum kimia akan sangat berperan dalam menentukan keberhasilan proses pembelajaran kimia baik dikelas maupun di kegiatan praktikum. Kemampuan guru kimia yang mumpuni akan menghasilkan kinerja yang optimal saat kegiatan praktik berlangsung. Hal ini juga merupakan salah satu tuntutan keprofesionalan seorang guru kimia sesuai dengan kompetensi pedagogik yang harus dikuasai oleh guru kimia.

Seorang guru dituntut untuk dapat menyajikan materi pembelajaran dengan berbagai pendekatan dan strategi yang kesemuanya diharapkan mampu membuat peserta didik menjadi lebih aktif. Oleh karena itu, guru harus kreatif dan inovatif menciptakan berbagai kegiatan yang tidak hanya dilakukan di dalam kelas, tetapi di luar kelas dan laboratorium. Menurut John W. Hansen \& Gerald G. Lovedahl (2004) "belajar dengan melakukan" merupakan sarana belajar yang efektif, artinya seseorang akan belajar efektif bila ia melakukan. Hal ini sesuai dengan yang diharapkan
e-ISSN : 2715-2537

p-ISSN : 2715-2545

kurikulum 2013 bahwa pembelajaran lebih ditekankan menggunakan metode pembelajaran scientifik, dengan demikian guru nantinya hanya akan menjadi fasilitator pembelajaran di kelas, sedangkan pembelajarannya akan berpusat pada siswa.

Program studi Kimia FKIP Unram sebagai salah satu instansi lembaga pendidikan penghasil guru kimia, ingin mengambil peran dan berinisiatif mengadakan pengabdian pada masyarakat sebagai salah satu bagian tridarma perguruan tinggi dengan judul 'Pengenalan Praktikum Kimia Sederhana Untuk Meningkatkan Motivasi Siswa SMA Masuk Program Studi Pendidikan Kimia FKIP Unram di SMAN 1 Pringgarata'. Adanya kegiatan tersebut diharapakan mampu meningkatkan motivasi siswa dalam belajar kimia serta merubah cara pandangnya terhadap pelajaran kimia menjadi pelajaran yang mudah, menarik, dan hadir dalam kehidupan kesehariannya, baik dalam lingkup akademik maupun dalam kehidupan mereka bermasyarakat secara umum. Kegiatan ini juga sekaligus dapat dijadikan ajang memperkenalkan program studi pendidikan kimia FKIP Unram sebagai salah satu program studi pencetak guru kimia dengan harapan minat siswa masuk perguruan tinggi khususnya pendidikan kimia akan meningkat.

\section{Metode}

Adapun metode pelaksanaan yang dapat dilakukan dalam kegiatan pengabdian ini adalah melalui serangkaian kegiatan yang akan dilaksanakan di SMAN 1 Priggarata, diantaranya : 1). Sosialisasi (ceramah dan diskusi) pentingnya Pelaksanaan kegiatan Praktikum, 2). Melaksanakan berbagai contoh praktikum sederhana, menggunakan alat dan bahan praktikum sederhana yang mudah dijumpai dalam kehidupan sehari-hari. Misalnya Pembuatan Larutan Gula, Larutan Garam (Memperkenalkan konsep stoikiometri), praktikum tentang laju reaksi (meniup balon dengan cuka dan backing soda), teori tentang konsep pengenceran dan sebagainya.

\section{Hasil dan Pembahasan}

Secara keseluruhan kegiatan ini dapat dikatakan berhasil. Pertama karena peserta yang hadir mencapai 47 orang siswa dari 50 siswa yang 
Junaidi et al, Jurnal Pengabdian Masyarakat Sains Indonesia 2020, 2 (1): 69-72. DOI : https://doi.org/10.29303/ipmsi.v2i1.14

diundang(Berdasarkan daftar hadir) yang terdiri atas siswa kelas XII IPA 1, XII IPA 2, dan XII IPA 3. Alasan kedua adalah dapat terlihat dari sikap antusias yang ditunjukkan siswa saat mengikuti setiap tahapan kegiatan yang dilakukan dalam kegiatan pengabdian terutama saat kegiatan yang ada melibatkan mereka dalam percobaan. Bentuk pelibatan siswa terjadi saat siswa ikut dilibatkan pada demostrasi (pembuatan air ajaib, mengupas telur tanpa menggunakan tangan, peniupan balon menggunakan cuka dan backing soda, pembuatan larutan garam, larutan gula, belajar konsep pengenceran).

Selain itu pada kegiatan pengabdian ini juga didemonstrasikan pembuatan larutan pada berbagai konsentrasi (menggunakan sirup sebagai solute dan air sebagai solvent) karena kegiatan pembuatan larutan ini merupakan kegiatan yang selalu dilakukan saat kegiatan praktikum akan dimulai, serta siswa juga dapat belajar tentang laju reaksi menggunakan media telur ayam (kecepatan laju reaksi $\mathrm{HCl}$ yang direaksikan dengan cangkang telur ayam, belajar tentang pengaruh perbedaan konsentrasi asetat dan backing soda pada laju pembentukan gas yang digunakan untuk meniup balon) serta belajar tentang konsep pengenceran pada larutan sirup. Kegiatan praktikum bisa dikatakan berhasil kalau tahapan awal kegiatan praktikum seperti pembuatan larutan, pemilihan alat dilakukan dengan tepat. Karena dalam kegiatan praktikum, melakukan suatu kesalahan dapat berakibat fatal terutama berkaitan dengan keselamatan jiwa.

Contoh sederhana yaitu cara memegang botol reagen, label pada botol tersebut harus dilindungi dengan tangan, karena label bahan tersebut mudah rusak kena cairan yang keluar dari botol ketika memindahkan isi botol tersebut. Banyak peralatan laboratorium terbuat dari gelas, bahan gelas tersebut mudah pecah dan pecahannya dapat melukai tubuh. Khususnya bila memasukkan pipa gelas kedalam prop-karet, harus digunakan sarung tangan untuk melindungi tangan dari pecahan kaca. Pada proses pemanasan suatu larutan, harus digunakan batu didih untuk mencegah terjadinya proses lewat didih yang menyebabkan larutan panas itu muncrat kemanamana, dan lain sebagainya.

Dengan demikian sikap antusias yang ditunjukkan siswa-siswa dalam mengikuti setiap tahapan kegiatan yang dilakukan dalam kegiatan
e-ISSN : 2715-2537

p-ISSN : 2715-2545

pengabdian terutama saat kegiatan pengenalan alat praktikum sederhana, Demonstrasi Kimia yang melibatkan siswa (Tanya jawab interaktif, demonstrasi kimia berupa percobaan sederhana misalnya mengupas telur menggunakan $\mathrm{HCl}$, Pembuatan Balon dengan menggunakan cuka dan backing soda, air ajaib melibatkan reaksi glukosa dan $\mathrm{KOH}$, diharapkan dapat menghilangkan stigma pada siswa bahwa kimia merupakan pelajaran yang sulit dan rumit karena berisi teori-teori yang abstrak dan rumus-rumus yang rumit.

Dengan demikian harapan dan tujuan dari kegiatan ini yaitu Untuk Meningkatkan Motivasi Siswa SMA Masuk Program Studi Pendidikan Kimia FKIP Unram di SMAN 1 Pringgarata melalui Pengenalan Praktikum Kimia Sederhana dapat tercapai.

\section{Faktor Pendorong}

Pada kegiatan ini terdapat faktor pendorong yang menyebabkan pentingnya kegiatan ini untuk dilaksanakan yaitu masih minimnya informasi tentang laboratorium sebagai media dalam proses belajar mengajar ilmu kimia (ranah Kognitif), sikap-sikap yang harus dilakukan dalam mengelola laboratorium (ranah Afektif) serta langkah-langkah yang harus diperhatikan/dilakukan pada saat demostrasi kimia (ranah Psikomotorik). Hal ini sangat penting untuk diketahui oleh siswa oleh karena laboratorium adalah suatu media yang dapat menjembatani teori yang diajarkan guru di dalam kelas dengan aplikasi teori tersebut menggunakan alat praktikum sederhana, demonstrasi kimia. Selain itu SMAN 1 Pringgarata Kab. Lombok Tengah juga termasuk salah satu sekolah yang memiliki fasilitas alat laboratorium kimia yang cukup memadai. Hal ini dapat dilihat dari banyak alat-alat gelas yang masih belum digunakan seperti beker, erlenmeyer, buret, pipet gondok, labu pengenceran dan sebagainya.

\section{Faktor Penghambat}

Peserta yang hadir kelas XII IPA 1, XII IPA 2 dan XII IPA 3 masih memiliki tingkat pengetahuan yang berbeda-beda tentang alat dan bahan kimia termasuk teori-teori yang sudah diperoleh dari guru hal ini menyebabkan penjelasan yang diberikan harus dengan analogi-analogi sederhana yang dekat dengan kehidupan mereka sehari-hari guna menjembatani adanya perbedaan pengetahuan yang dimiliki setiap siswa tanpa 
Junaidi et al, Jurnal Pengabdian Masyarakat Sains Indonesia 2020, 2 (1): 69-72 DOI : https://doi.org/10.29303/ipmsi.v2i1.14

mengurangi makna/prinsip dasar dari teori-teori dalam ilmu kimia. Kendala lain yang dihadapi adalah jumlah kegiatan demonstrasi yang dapat ditunjukkan berkaitan dengan durasi waktu yang tersedia saat kegiatan berlangsung.

\section{Kesimpulan}

Berdasarkan hasil evaluasi terhadap pelaksanaan kegiatan pengabdian ini maka dapat disimpulkan sebagai berikut :

1. Kegiatan pengabdian ini dapat dinyatakan sangat berhasil dengan nilai keberhasilan mencapai 94\%. Hal ini ditunjukkan dengan setiap tahapan yang direncanakan dapat dilaksanakan dengan baik dan lancar, meskipun kendalanya hanya saat menyesuaikan alokasi waktu pelaksanaan (hari selasa, 29 Oktober 2019), karena kegiatan berlangsung saat proses belajar mengajar pada minggu tersebut sedang aktif dan mendekati ujian akhir semester.

2. Pengabdian ini sangat bermanfaat tidak hanya bagi siswa tapi bagi guru pembina maupun sekolah. Karena adanya kegiatan semacam ini dapat menambah wawasan keilmuwan dan keterampilan bagi guru. Sedangkan bagi sekolah semakin tinggi minat belajar siswa diharapkan akan memberikan korelasi positif pada peningkatan prestasi belajar siswa. Dengan demikian kegiatan ini diharapkan mampu mendukung pembelajaran kimia dilakukan secara terintegrasi baik di kelas maupun di laboratorium.

\section{Saran}

Perlu dilakukan pengabdian lanjutan dengan topik yang bervariatif dalam upaya meningkatkan wawasan serta pengetahuan siswa serta melakukan kegiatan pada saat kegiatan proses belajar mengajar sedang tidak aktif untuk menghindari terganggunya kegiatan belajar yang sudah dirancang dengan baik.

\section{Daftar Pustaka}

Adijuwana Hendra. 1992. Manajemen Laboratorium. Bogor: Istitut Pertanian Bogor.
e-ISSN : 2715-2537

p-ISSN : 2715-2545

Budiono Djoko. 1992. Pengantar Kegiatan Laboratorium Biologi. Surabaya: University Press IKIP Surabaya.

John W. Hansen \& Gerald G. L. 2004. Developing technology teachers : questioning the industrial tool use model. Journal of Technology Education. 15 (2), 20 - 32.

Mulyono. 2006. Membuat Reagen Kimia. Jakarta: Bumi Aksara.

Padmawinata Djupri, dkk. 1983. Pengelolaan Laboratorium IPA. Dirjen Dikti, Jakarta.

Sudarmadji Slamet, dkk. 1984. Prosedur Analisa untuk Bahan Makanan dan Pertanian. Liberty, Yogyakarta.

Tim. 2002. Pedoman Standar Minimal Pendayagunaan Peralatan Laboratorium Kimia. Jakarta: Direktorat Pendidikan Menengah Umum

Tim. 2004. Penanganan Bahan - bahan Kimia Berbahaya dan Beracun Serta keselamatan Kerja. Bandung: Pusat Penelitian Kimia. 